\title{
A Review of the Agriculture Literature in Malaysian and Indonesian Accounting Journals
}

\author{
Hasri Mustafa ${ }^{1}$, Retno Martanti Endah Lestari ${ }^{2 *}$ \\ ${ }^{1}$ Department of Accounting and Finance, Faculty of Economics and Management, \\ Universiti Putra Malaysia, 43400, UPM Serdang, Selangor, MALAYSIA \\ ${ }^{2}$ Department of Accounting, Faculty of Economics, \\ Universitas Pakuan, Bogor, 16143, INDONESIA \\ *Corresponding Author
}

DOI: https://doi.org/10.30880/jstard.2021.03.02.005

Received 12 November 2020; Accepted 15 June 2021; Available online 15 December 2021

\begin{abstract}
This article discusses the scope related to Malaysian and Indonesian accounting research in agricultural literature. This discussion was based on two well-known Malaysian accounting journals and many were referred from 2008 to 2016, recognized as Accounting Overview Malaysia (MAR) and Asian Business and Accounting Journal (AJBA), and three Indonesian accounting journals namely Economic \& Financial Studies (SEZ), Gadjah Mada International Business Journal (GamaIJB) and Indonesian Accounting and Finance Journal (JAKI). In MAR and AJBA, Corporate Governance, Auditing, Financial Accounting Reporting, and Management Accounting are the most widely published topics. In SEZ, Economy, Finance, Public Sector Accounting and Taxation; GamaIJ, Management / Managerial Accounting and Finance; and JAKI, Management / Managerial Accounting, Financial Accounting, and Reporting Audit are the most widely published topics. This article proposes peculiarities, noncompany and non-professional attributes as opportunity-researched variable fields for future agricultural studies. This article concludes with a reminder of the direction that leads to Malaysian and Indonesian accounting research, including the ontological difference between agricultural studies and accounting minutes while the latter seeks to fulfill generalizations, company attributes and stereotyped-research-variable professionals. It was concluded there is no difference in the average number of journals published in Malaysia and Indonesia with the $t$ test.
\end{abstract}

Keywords: Accounting, agriculture, opportunity, stereotype, Malaysia and Indonesia

\section{Introduction}

Farm financial recording systems have suffered from an undeserved and misleading reputation as a narrow or technical topic. These sentiments get portrayed especially when those who have labelled accountants and auditors will perhaps agree that financial aspect is really no more than planning for big agriculture and commodity companies. Accounting, by its very nature, must be based on the volume of transaction and for organizations and shareholders [1], $[2]$.

This is the issue that is central to the study of most agricultural studies. As a result, accounting writings, particularly from Asian country, do not feature much in the journals. Pushes from farm recording and accounting systems for agriculture have not been done with serious especially for agriculture industry, which poverty is usually synonymous with.

This article acknowledges the limitation. It appreciates the view that agriculture is somehow missing in accounting literature although literature has quoted that the historical development of accounting was closely connected to agriculture [3]-[5]. This is discussed in the review of the two leading Malaysian accounting journals; Malaysian Accounting review (MAR) and Asian Journal of Business and Accounting (AJBA), and three leading Indonesian accounting journals; Jurnal Akuntansi Keuangan Indonesia (JAKI), Gadjah Mada International Journal of Business (GamaIJB) and Kajian Ekonomi 
$\&$ Keuangan (KEK). The article aims to provide a description of the research nature and also report on prevalent research scopes based on number of their publications.

The next section details the studied-variables, followed by a classification of the variables into groups which comprise of opportunity and stereotype-researched-variables. With this classification, a suggestion for agriculture-based research is proposed to the Malaysian and Indonesian accounting journals. After the classification process, the next step the writer tests using the average $t$ test to see the difference in the average number of journals published in Malaysia and Indonesia in the accounting field.

Later, the article concludes with some observations as to why and how agriculture might usefully evolve in Malaysian and Indonesian accounting research.

\section{Literature Review}

Agriculture is now again in the headlines because higher food prices are increasing food insecurity and poverty. In the coming years it will be essential to increase food productivity and production in developing countries. This however requires finding viable solutions to a number of complex technical, institutional and policy issues including land markets, research on seeds and inputs; agricultural extension; credit; rural infrastructure; storage; connection to markets; rural nonfarm employment and food price stabilization. The paper by [6] reviews in turn the role played by agriculture in the development process and the interactions between agriculture and other economic sectors; the determinants of the Green Revolution and discuss the foundations of agricultural growth; issues of income diversification by farmers; approaches to rural development; and finally issues of international trade policy and food security which are at the root of the crisis in agricultural commodity volatility in the past few years.

Many believe, in an age where agriculture appears to play important role of land-based economy, much social information relating to farmers can be summarized as to include: farmer's income and food security [7], fertilizer subsidy [8], [9], agriculture fish and the associated health risk to farmers [10], [11], machine-scheduling for rice production [12], irrigation scheme [13], the ideological struggle amongst farmers [14], and tenancy owner-cultivated agriculture plots [15].

As stated by [16], "the agriculture-for-development mission remains substantially incomplete." According to [6] there are still major gaps in the research. In our view, economists should focus as a priority on the most pressing issues, which include property rights, agricultural extension, rural infrastructure, and food price stabilization. The most pressing issue at present is to make progress on food security and put in place effective coping mechanisms for poor people. Economists and policymakers have been unable to find adequate policy instruments to limit food price volatility.

Policies governing accounting in agriculture for the beginning in 2003 IASC (International Accounting Standard Committee) approved the accounting standard for agriculture sector that is IAS-41 (International Accounting Standard) agriculture. Where the IAS-41 agriculture contains the standard of accounting treatment which includes measurement, presentation, disclosure and reporting of a biological asset for agricultural entities. According to IAS-41 biological assets are defined as plants and animals that live and are controlled by agricultural entities as a result of past events.

There are several Asean countries which have already applied IAS-41 for their agricultural entity. In early 2005 the Philippine had first adopted the IAS-41. PAS-41 (Philippine Accounting Standards) is the name for the standard of accounting treatment of agriculture in Philippine.Tahun 2008 Singapore has enacted FRS-41 designation of agricultural accounting standards in Singapore as the basis of accounting treatment of biological assets in the country. Furthermore Malaysia is the third Asean country to adopt IAS-41 agriculture for its agricultural entity. In 2012 Malaysia began applying MAS-7 as an accounting standard for its agricultural entity.

Beginning in 2017 Thailand has begun to actively implement TAS-41 (Thai Accounting Standard) as a satandar of accounting treatment for its agriculture sector where Thailand adopts full IAS-41 agriculture. As for the country of Vietnam is still in the process of perevisian IAS-41 agriculture.

\section{Methodology}

This study uses a type of statistical description research which is a statistical technique used to summarize the data included in it is the amount of data, average, and standard deviation. The type of research used is comparative research that uses a quantitative approach. The location of the study was conducted in Indonesia and Malaysia with 3 accounting journals in Indonesia and 2 accounting journals in Malaysia. In this study the determination of samples was carried out using a nonprobability sampling technique.

This study uses secondary data sources. The document taken in this study is a list of journal titles published from 2008 to 2018 both journals in Malaysia and 2008 to 2018 in the KEK journal in Indonesia, 2008 to 2018 at Gadjah Mada International Journal of Business (GamaIJB) and 2008 to 2018 for journals published in the Indonesian Accounting and Finance Journal (JAKI).

In this study compares the average of number journals that published in Malaysia and Indonesia using statistical method, independent samples t-test. 


\section{Result and Discussion}

\subsection{Malaysia, Accounting Research and The Direction}

Tables 1 and 2 show within this 10 years gap, there were 134 articles issued in MAR, and 134 articles too issued in AJBA. As seen, none of these articles destined for accounting agriculture although there were 18 researched areas in MAR, and 18 researched areas in AJBA, including Finance, Banking, Ethics, Criminology, Economics, Education, Economics, Consumer Behaviour and Marketing which were non-genuine accounting disciplines.

Table 1 - Articles published in Malaysian Accounting Review (MAR) from year 2008 to 2018

\begin{tabular}{clclc}
\hline No & Scope & Articles & Group or Non-Group & \\
\hline 1 & Corporate Governance & 25 & Group & 3 \\
2 & Islamic Finance and Banking & 12 & Non-Group & \\
3 & Auditing & 11 & Group & 3 \\
4 & Financial Accounting and Reporting & 12 & Group & 3 \\
5 & Sustainability Reporting & 9 & Group & 2 \\
6 & Finance & 17 & Non-Group & \\
7 & Public Sector Accounting & 9 & Group & 2 \\
8 & Taxation & 5 & Group & 1 \\
9 & Management Accounting & 7 & Group & 2 \\
10 & Ethics & 4 & Non-Group & \\
11 & Financial Criminology & 3 & Non-Group & \\
12 & Islamic Finance and Banking & 4 & Non-Group & \\
13 & Accounting Information System & 3 & Group & 1 \\
14 & Internet Financial Reporting & 1 & Group & 1 \\
15 & Corporate Social Responsibility & 3 & Group & \\
16 & Economics & 2 & Non-Group & \\
17 & Education & 5 & Non-Group & \\
18 & Organizational Behavior & 2 & Non-Group & \\
\hline Total & & 134 & & \\
\hline
\end{tabular}

Note: 1. Accounting discipline:- Group 1 ( $<5$ articles); Group 2 (between $5-10$ articles); Group 3 ( $>10$ articles)

2. Non- genuine accounting discipline:- Non-Group

Both tables 1 and 2 use number of articles published to refer as Group 1 ( $<5$ artciles), Group 2 (between $5-10$ articles), and Group 3 ( $>10$ articles). As seen, both MAR and AJBA share the view that Corporate Governance was their Group 3. For Auditing and Financial Accounting, both were placed as Group 3 and Group 2 in MAR, but as Group 2 and Group 3 in AJBA. Sustainability Reporting and Public Sector Accounting were in Group 2 in MAR and Group 1 in AJBA. Taxation, Management Accounting, Internet Financial Reporting, Accounting Information System, and Corporate Social Responsibility were in Group 1 in MAR and AJBA. In general, both MAR and AJBA had the same pattern of research in accounting treatise.

Table 2 - Articles published in Asian Journal of Business and Accounting (AJBA) from year 2008 to 2018

\begin{tabular}{llclc}
\hline No & Scope & Articles & Group or Non-Group \\
\hline 1 & Finance & 34 & Non-Group & 3 \\
2 & Corporate Governance & 18 & Group & 3 \\
3 & Financial Accounting and Reporting & 16 & Group & 3 \\
4 & Management/ Managerial Accounting & 15 & Group & 2 \\
5 & Auditing & 6 & Group & 1 \\
6 & Economics & 6 & Non-Group & \\
7 & Public Sector Accounting & 5 & Group &
\end{tabular}




\begin{tabular}{clrlr}
9 & Islamic Finance & 4 & Non-Group & \\
10 & Taxation & 4 & Group & 1 \\
11 & Consumer Behaviour & 4 & Non-Group & \\
12 & Marketing & 3 & Non-Group & 1 \\
13 & Accounting Information System & 3 & Group & \\
14 & Organizational Behavior & 4 & Non-Group & 1 \\
15 & Education & 3 & Non-Group & 1 \\
16 & Sustainability Reporting & 2 & Group & \\
17 & Corporate Social Responsibility & 2 & Group & \\
18 & Banking & 2 & Non-Group & \\
\hline Total & & 134 & & \\
\hline
\end{tabular}

Note: 1. Accounting discipline:- Group 1 ( $<5$ articles); Group 2 (between $5-10$ articles); Group 3 ( $>10$ articles)

2. Non- genuine accounting discipline:- Non-Group

\subsection{Indonesian, Accounting Research and the Direction}

Tables 3, 4 and 5 show an observation on three renowned and widely referred Indonesian accounting journals Kajian Ekonomi \& Keuangan (KEK), Gadjah Mada International Journal of Business (GamaIJB) and Jurnal Akuntansi dan Keuangan Indonesia (JAKI). The three are peer-reviewed journals published by Badan Kebijakan Fiskal Kementrian Keuangan Republik Indonesia, Faculty of Economics and Business, Universitas Gajah Mada and Universitas Indonesia fespectively. Number of publications is based on KEK's 2008 to 2018, GamaIJB's 2008 to 2018 and JAKI's 2008 to 2018.

JAKI has obtained an accreditation from Directorate General of Research and Development Strengthening, Ministry of Research, Technology, and Higher Education of the Republic of Indonesia. JAKI is internationally has been indexed in DOAJ, Google Schoolar, ISJD, IPI and SINTA. GamaIJB is nationally accredited by the Indonesian Ministry of Education Directorate General of Higher Education and internationally indexed by SCOPUS (Elsevier), BUSINESS SOURCE COMPLETE (EBSCO), INFORMIT (RMIT Publishing), NSD (Norwegian Social Science data Services), and EconLit. KEK which was also known as Kajian Ilmiah Ekonomi dan Keuangan (KIEK) receives accreditation of Indonesian Institute of Sciences.

Table 3 - Articles published in Kajian Ekonomi \& Keuangan (KEK) from year 2008 to 2018

\begin{tabular}{clclc}
\hline No & Scope & Articles & Group or Non-Group \\
\hline 1 & Economics & 49 & Non-Group & \\
2 & Finance & 16 & Non-Group & 3 \\
3 & Public Sector Accounting & 21 & Group & 3 \\
4 & Taxation & 25 & Group & \\
5 & Banking & 8 & Non-Group & 1 \\
6 & Education & 2 & Non-Group & 1 \\
7 & Sustainability Reporting & 1 & Group & 1 \\
8 & Corporate Social Responsibility & 3 & Group & \\
9 & Financial Accounting And Reporting & 1 & Group & \\
10 & Islamic Finance & 2 & Non-Group & \\
11 & Organizational Behaviour & 3 & Non-Group & \\
\hline Total & & 131 & & \\
\hline
\end{tabular}

Note: 1. Accounting discipline:- Group 1 ( $<5$ articles); Group 2 (between $5-10$ articles); Group 3 ( $>10$ articles) 2. Non- genuine accounting discipline:- Non-Group 
Table 4 - Articles published in Gadjah Mada International Journal of Business (GamaIJB) from year 2008 to 2018

\begin{tabular}{|c|c|c|c|c|}
\hline No & Scope & Articles & Group or Non Group & \\
\hline 1 & Finance & 38 & Non Group & \\
\hline 2 & Organizational behaviour & 30 & Non Group & \\
\hline 3 & Management/Managerial accounting & 15 & Group & 3 \\
\hline 4 & Economics & 14 & Non Group & \\
\hline 5 & Consumer Behaviour & 13 & Non Group & \\
\hline 6 & Financial Accounting And Reporting & 3 & Group & 1 \\
\hline 7 & Education & 6 & Non Group & \\
\hline 8 & Corporate Governance & 7 & Non Group & \\
\hline 9 & Marketing & 7 & Non Group & \\
\hline 10 & Banking & 6 & Non Group & \\
\hline 11 & Auditing & 6 & Group & 2 \\
\hline 12 & Islamic Finance & 6 & Non Group & \\
\hline 13 & Corporate Social Responsibility & 6 & Non Group & \\
\hline 14 & Taxation & 1 & Group & 1 \\
\hline 15 & Sustainability Reporting & 3 & Non Group & \\
\hline 16 & Public Sector Accounting & 2 & Group & 1 \\
\hline 17 & Ethics & 2 & Non Group & \\
\hline Total & & 165 & & \\
\hline
\end{tabular}

Note: 1. Accounting discipline:- Group 1 ( $<5$ articles); Group 2 (between $5-10$ articles); Group 3 ( $>10$ articles)

2. Non- genuine accounting discipline:- Non-Group

Table 5 - Articles published in Jurnal Akuntansi dan Keuangan Indonesia (JAKI) from year 2008 to 2018

\begin{tabular}{clllc}
\hline No & \multicolumn{1}{c}{ Scope } & \multicolumn{2}{c}{ Articles } & \multicolumn{2}{c}{ Group or Non-Group } \\
\hline 1 & Management/Managerial Accounting & 22 & Group & 3 \\
2 & Auditing & 20 & Group & 3 \\
3 & Finance & 13 & Non Group & 3 \\
4 & Financial Accounting And Reporting & 10 & Group & 2 \\
5 & Taxation & 8 & Group & 2 \\
6 & Corporate Governance & 7 & Group & 2 \\
7 & Public Sector Accounting & 6 & Group & 1 \\
8 & Islamic Finance & 5 & Non Group & \\
9 & Accounting Information System & 4 & Group & Non Group \\
10 & Corporate Social Responsibility & 3 & Non Group & \\
11 & Education & 2 & & \\
12 & Sustainability Reporting & 2 & & \\
13 & Organizational Behaviour & 1 & & \\
\hline Total & & 103 & & \\
\hline
\end{tabular}

Note: 1. Accounting discipline:- Group 1 ( $<5$ articles); Group 2 (between $5-10$ articles); Group 3 ( $>10$ articles)

2. Non- genuine accounting discipline:- Non-Group

From the tables, within this 10 years gap, there were 131 articles issued in KEK, 165 articles in GamaIJB and 103 articles issued in JAKI. As seen, none of these articles destined for accounting agriculture although there were 11 and 17 researched areas in KEK and GamaIJB, and 13 researched areas in JAKI, including Economics, Finance, Banking, Education, Islamic Finance, Organizational Behaviour, and Consumer Behaviour, which were non-genuine accounting 
disciplines. According to tables 4, 5 and 6, only articles published in KEK under the scope of Public Sector Accounting and Taxation. Management/Managerial accounting and Financial Accounting and Reporting in GamalJB that were grouped as Group 3 ( $>10$ articles). As seen, although Management/Managerial accounting and Financial Accounting and Reporting were placed as the top research scope in JAKI, they were only categorized as Group 2. In general, both GamaIJB and JAKI have the same pattern of research in accounting treatise, which actually have no big difference with KEK's.

Furthermore, this study would like to see the difference in the average number of journals that are published between the two countries of Indonesia and Malaysia in the general accounting field, statistical test tests are carried out, with the results as shown in the following table :

Table 6 - Descriptive statistical table

\begin{tabular}{llrrr}
\hline \multicolumn{1}{c}{ Country } & $\mathrm{n}$ & \multicolumn{1}{c}{ Mean } & $\begin{array}{c}\text { Standard } \\
\text { Deviation }\end{array}$ & Standard Error \\
\hline Malaysia & 20 & 13.4 & 13.62 & 3.046 \\
Indonesia & 18 & 22.17 & 18.92 & 4.460 \\
\hline
\end{tabular}

Based on the table above, it can be explained that the average number of journals published in Malaysia is 13 with a standard deviation of 14, whereas in Indonesia, the average number of journals published is 22 journals with a standard deviation of 19 .

$t$ test or t test is one of the statistical methods used to test the differences in the average of two groups. In this study the $t$ test will be used to test the differences in the average number of journals published in Malaysia and Indonesia. The results of the analysis are shown in the table below.

Table 7 - T Test the average number of journals published

\begin{tabular}{ccccc}
\hline T statistics & df & P value & Conf int lower & Con tint upper \\
-1.651 & 36 & 0.1074 & -19.53 & 2.001 \\
\hline
\end{tabular}

Based on the above test, a p-value of 0.1074 is obtained. This value is smaller than the real level of 0.05 , so it is concluded that there is no difference in the average number of journals published in Malaysia and Indonesia.

\subsection{Analysis: The Studied Variables}

It is useful to evaluate the studied variables in details since they provide understanding of the journals' stature, interest and future direction of where the direction that Malaysian and Indonesian accounting research is leading to.

Table 5 below summarizes the studied variables of all the groups 2 and 3 for MAR, AJBA, KEK, GamaIJB and JAKI. These two groups of 2 and 3 represent the highest number of publications in specific scope as seen in previous tables 1, 2, 3 and 4.

Table 8 - Studied-variable in groups 2 and 3 in all articles

\begin{tabular}{|c|c|c|c|c|}
\hline No & Journal & Scope & Group & Studied Variables \\
\hline 1 & MAR & $\begin{array}{l}\text { Corporate } \\
\text { Governance }\end{array}$ & 3 & $\begin{array}{l}\text { Financial literacy, frequency of audit committee meeting, multiple } \\
\text { directorships, independence of audit committee, and external audit; } \\
\text { Board independence, director's ownership, institutional ownership, } \\
\text { board duality/designation; Human capital, Relational capital, } \\
\text { structural capital; Board ownership/size and shareholder } \\
\text { ownership; Woman Directors on Board, Multiple Directorships, } \\
\text { family, Earnings conservatism, impact of ENRON case;Attitude } \\
\text { toward behaviour, subjective norm; Ownership Concentration, } \\
\text { Firm Specific Characteristics, Leverage; Strategic Management } \\
\text { Accounting, the adoption of IT, Non-capitalised intangibles assets, } \\
\text { capitalised asset; Gender and Ethnic Diversity; GLC and non GLC; } \\
\text { Types of REM, abnormal CFO, abnormal COGS, and abnormal } \\
\text { DISEXP; Corporate ownership: family, public, institutional; Joint } \\
\text { Auditor Tenure, joint auditor pair; governmennt, managerial, } \\
\text { institutional; Maslow s hierarchy of needs. }\end{array}$ \\
\hline
\end{tabular}




\begin{tabular}{|c|c|c|c|c|}
\hline No & Journal & Scope & Group & Studied Variables \\
\hline 2 & MAR & Auditing & 3 & $\begin{array}{l}\text { The financial ratio variables: working capital, sales, inventory, } \\
\text { debt, tax rate, account receivables; The proportion of independent } \\
\text { directors, Directors" tenure, The proportion of financial expertise } \\
\text { on the board, The proportion of concentrated ownership, The board } \\
\text { attributes; Current earnings, chairman religion; FRS } 3 \text { Business } \\
\text { Combination; governance, market value; Firm objectivity, audit } \\
\text { fees, work performance. }\end{array}$ \\
\hline 3 & AJBA & $\begin{array}{l}\text { Corporate } \\
\text { Governanc } \\
\text { e }\end{array}$ & 3 & $\begin{array}{l}\text { Board independence, CEO duality, deferred tax assets, liabilities, } \\
\text { audit tenure, audit rotation, duality board, market reponse, } \\
\text { independent director, audit fee, affiliated big firms, IFRS-related } \\
\text { consulting services of an auditor, types of corporate governance } \\
\text { information, types of institutional ownership of IFIs, method of } \\
\text { reported earnings: cost, equity, the impact of interactive reviews, } \\
\text { the effectiveness of Group Support System (GSS), perceived } \\
\text { information asymmetry, informativeness, usefulness, norm, firm } \\
\text { credit ratings, ownership structure, probability of default, goal } \\
\text { orientation, government regulation, brand awareness, brand } \\
\text { association, attitude towards the brand, brand loyalty, brand } \\
\text { preference, perceived quality, leadership commitment, strategic } \\
\text { planning, continuous improvement, student focus, process focus, } \\
\text { academic staff involvement, training and learning, rewards and } \\
\text { recognition, management by fact. }\end{array}$ \\
\hline 4 & AJBA & $\begin{array}{l}\text { Financial } \\
\text { Accountin } \\
\text { g and } \\
\text { Reporting }\end{array}$ & 3 & $\begin{array}{l}\text { Manager's motives for customer deposits window-dressing: bank } \\
\text { liquidity, the role of instrumental beliefs (i.e. perceived ease of use } \\
\text { and usefulness), socialpsychological belief (i.e. perceived } \\
\text { confirmation), change messages, communication flows, } \\
\text { professional accounting education, professional competency, } \\
\text { professional commitment, pre-bid dividend payout ratio as } \\
\text { ordinary dividends paid (year t-1 interim dividend), proposed (year } \\
\text { t-1 final dividend), board size, proportion of independent outside } \\
\text { directors on the board, CEO duality structure, the number of the } \\
\text { board meetings, ownership structure: concentration, foreign, } \\
\text { family, institutional, corporate gorvernance structure }\end{array}$ \\
\hline 5 & KEK & $\begin{array}{l}\text { Public } \\
\text { Sector } \\
\text { Accountin } \\
\mathrm{g}\end{array}$ & 3 & $\begin{array}{l}\text { Agriculture insurance; premium subsidy; public service obligation; } \\
\text { state budget; SOE, employment privat investment; regional } \\
\text { government spending, funding; health insurance for the poor; } \\
\text { regional government }\end{array}$ \\
\hline 6 & KEK & Taxation & 3 & $\begin{array}{l}\text { burden of tax; effective tax rates; income distribution; taxes on } \\
\text { production, economic growth; official economy; underground } \\
\text { economy; tax rate, Value added tax; efficiency and effectiveness }\end{array}$ \\
\hline
\end{tabular}

\begin{tabular}{|llll}
7 & GamaIJB & $\begin{array}{l}\text { Managem } \\
\text { ent/Manag } \\
\text { erial } \\
\text { Accountin } \\
\mathrm{g}\end{array}$ \\
& & 3 \\
& & \\
\hline 8 & GamaIJB & $\begin{array}{l}\text { Financial } \\
\text { Accountin } \\
\text { g and } \\
\text { Reporting }\end{array}$ \\
& & 3 \\
& &
\end{tabular}




\begin{tabular}{|c|c|c|c|c|}
\hline No & Journal & Scope & Group & Studied Variables \\
\hline 9 & JAKI & $\begin{array}{l}\text { Managem } \\
\text { ent/Manag } \\
\text { erial } \\
\text { Accountin } \\
\mathrm{g}\end{array}$ & 2 & $\begin{array}{l}\text { depth, asymmetric information; debt financing; equity financing; } \\
\text { investment, adjustment and reform program; balance sheet } \\
\text { vulnerability; economic crises (1997); accounting fundamentals; } \\
\text { book value; earnings yield; growth opportuni-ties; short-run and } \\
\text { long-run investment scalabilities; trading strategy; value relevance, } \\
\text { discretionary accruals; financial derivatives; the value relevance } \\
\text { of earnings; thevalue relevance of equity, Indonesia flow of } \\
\text { funds; macroeconomic management, diverse information; market } \\
\text { depth and informed traders, accounting for goodwill; costly } \\
\text { contracting theory; a cross-country study, capital structure; } \\
\text { inventories; monetary policyfinancial statement frauds; fraud } \\
\text { triangle; fraud risk factors; SAS 99, } \\
\text { tax shelter; notice of tax deficiency; tax penalty; accrual earnings } \\
\text { management; real earnings management, abnormal accruals, } \\
\text { earnings management, predictive content of accruals, signaling } \\
\text { theory, earnings management, expected dividend, premanaged } \\
\text { earnings, dividend thresholds, behavioral finance, herding } \\
\text { behavior, information asymmetry, information cascades, } \\
\text { information asymmetry; cost of equity capital; discretionary } \\
\text { accrual; income smoothing; earnings quality; asimetri informasi; } \\
\text { cost of equity capital; discretionary accrual; competitive strategy, } \\
\text { MAS information, customer-related performance }\end{array}$ \\
\hline 10 & JAKI & $\begin{array}{l}\text { Financial } \\
\text { Accountin } \\
\text { g And } \\
\text { Reporting }\end{array}$ & 2 & $\begin{array}{l}\text { financial statement quality, SMEs, FAS EWPA, value relevance, } \\
\text { book value of equity, earnings, IFRS, noncontrolling interest, } \\
\text { consolidated financial statement, value relevance, PSAK } 4 \\
\text { (Revised 2009), accounting standards; changes in foreign } \\
\text { exchange rates; earnings informativeness; academic dishonesty, } \\
\text { the theory of planned behaviour, situational factors, individual } \\
\text { factors }\end{array}$ \\
\hline 11 & JAKI & Auditing & 2 & $\begin{array}{l}\text { accrual earnings management, audit quality, composite measure, } \\
\text { audit quality metric score (AQMS), fair value, value relevance, } \\
\text { auditor tenure, auditor size, modified audit opinion, borrowing } \\
\text { cash flow, investment cash flow, operating cash flow, experimental } \\
\text { auditing research, experimental method, auditing, modified audit } \\
\text { opinion, borrowing cash flow, investment cash flow, operating } \\
\text { cash flow, audit, dysfunctional, job stress, personality, } \\
\text { procurement fraud; system weakness; subjective norms; attitude; } \\
\text { perceived behavioral control; intention to engage fraud }\end{array}$ \\
\hline
\end{tabular}

The above studied variables show both research in Malaysia and Indonesia are based on the assumption that researchers have already had the idea on the direction that they researching for. In Corporate Governance and Auditing Scope, MAR researchers re helping to institute the perceptiveness and the acceptance of variables such as 'firm value', 'stockholder wealth', 'stock market efficiency', 'demand and supply' - those labeled 'mainstream neoclassical economics' - to become so prominent. For AJBA's publications on Corporate Governance and Financial Accounting and Reporting, their picture relates to accounting are much of the focus referring to the assumption of functional and technical not social and cultural.

In Public Sector Accounting and Taxation research of KEK provide a reference for the government to implement its regulations through various studies such as budget performance; budgeting; spending review, there is an interesting thing that there are results of research that produce conclusions there are differences in the allocation of expenditure grants, social assistance and capital expenditure between the period before and at the time of post-conflict local election. in research in the field of taxation, there is one that provides a model in certain natural gas pricing policies that can improve the performance of the national economy and there is any findings also contribute to the field of tax literature by providing simultaneous empirical models including conforming and non-conforming tax avoidance model, which has been relatively unexplored in prior studies.

In Management/Managerial Accounting, Financial Accounting And Reporting and Auditing research of GamaIJB and JAKI in general, research revolves around how to manage earnings in companies, such as earnings management and the predictive ability of earnings versus cash flow data to predict future cash flows and too how management makes conscious and systematic efforts to transform ideas from the best practice within the company as well as from its 
competitors. All of them contributed to the idea of how to make the company continue to survive in this competitive situation, how various studies on the government to produce appropriate regulatory models and various processes, as well as auditing models examined for the survival of the entities.

It is seen that overall, generalization, firm attributes and professionals stereotype-researched-variable are the publication focus of the above journals. Generalization refers to the case where a number of sample is typical of the population from which the sample is drawn. For this type of research, as a working procedure, a criterion for a good analysis generally depends very much on how 'fit' the findings are in the world of the given model. This is the reason why in MAR, AJBA, JAKI, GamaIJB and KEK, firm attributes and professionals stereotype-researched-variable are common. Auditors, CEO, shareholders, bankers and the like are imprisoned with the so-called organizational performance. They are chosen to represent morale in organization which are very different from those used to stand for morale in an agriculture field.

This article proposes particularity, non-firm attributes and non-professionals as opportunity-researched-variable areas for future agriculture studies. Most agriculture farmers do not talk about profit, they talk about living and hardship. While accounting researchers are busy searching for accountability but correspond to the words like 'success', 'measure', 'earnings per share', they are looking for food availability, off-farm employment and rural out-migration (see Patel et al., 2015). In our view this inherited 'myopic view' has made accounting seems to be situated far from responsing to the people and environment, far from the knowledge of aiming to solve poverty, unemployment and net carbon emission which are actually our universal struggle (Yunus, 2017).

\section{Conclusion}

There may be something we Malaysian and Indonesian researchers should look into: What can we learn from this pattern of research? How far can agriculture be perceived and accepted in Malaysian and Indonesian accounting literature? Why Finance, Banking, Economics, Education, Economics, Consumer Behaviour and Marketing, but not any single agriculture article appear in both Malaysian and Indonesian accounting journals? Presently, in Asian country, there is an accounting standard for agriculture. The MASB (Malaysian Accounting Standards Board) and the IAI (Institute of Indonesia Chartered Accountants) have approved the release of MFRS (Malaysian Financial Reporting Standards) 141 Agriculture and SFAS (Statement of Financial Accounting Standards) 69 Agriculture for distribution to professional accounting bodies, regulator, users and other interested individuals and organizations for comments. Both MFRS 141 and SFAS 69 are identical with IAS 41 Agriculture which was issued by the IASB (International Accounting Standards Board) on 22 February 2001 and effective for annual periods beginning on and after 1 January 2012. The objective of this standard is to prescribe the accounting treatment, financial statement presentation, and disclosures related to agricultural activity, which are not covered in other standards.

Although these journals may not accurately represent the view of research patterns in Malaysian and Indonesian accounting literature, they have carry some weightages to accounting treatise. The article proposes particularity, nonfirm attributes and non-professionals as opposed to generalization, firm attributes and professionals stereotyperesearched-variable as opportunity-researched-variable areas for future agriculture studies.

Based on testing using the $t$ test and some previous explanations it can be concluded that there is no difference in the average number of journals published in Malaysia and Indonesia, and generally these journals have not examined accounting for agriculture, this is strengthening a review of agriculture literature in Malaysia and Indonesian accounting journal.

\section{Acknowledgement}

The author would like to thank Department of Accounting, Faculty of Economics Universitas Pakuan, Bogor, Indonesia for supporting this research work.

\section{References}

[1] J. Hooks and R. Stewart, "The changing role of accounting: From consumers to shareholders," Crit. Perspect. Account., vol. 29, pp. 86-101, 2015, doi: 10.1016/j.cpa.2015.03.001.

[2] M. Messner, “Accounting practice,” Foreign Exch. Options, pp. 355-381, 1998, doi: 10.1016/b978-1-85573253-7.50022-3.

[3] R. K. Elliott and P. D. Jacobson, "The evolution of the knowledge professional," Account. Horizons, vol. 16, no. 1, pp. 69-80, 2002, doi: 10.2308/acch.2002.16.1.69.

[4] R. H. Juchau, "Accounting developments and implications for farm business."

[5] M. Giraudeau, "The farm as an accounting laboratory: an essay on the history of accounting and agriculture," Account. Hist. Rev., vol. 27, no. 2, pp. 201-215, 2017, doi: 10.1080/21552851.2017.1314014.

[6] Deutsche Lufthansa AG, "Sustainability report," Dtsch. Lufthansa AG, p. 120, 2014, doi: 10.1016/j.jembe.2007.06.028. 
[7] M. Alam, C. Siwar, W. Murad, and M. E. bin Toriman, "Impacts of Climate on Agriculture and Food Security Issues in Malaysia, An Empirical Study on Farm Level Assessment," vol. 14, no. 3, pp. 431-442, 2011, doi: 10.31219/osf.io/mdqpz.

[8] and A. R. Nurul Nadia Ramli, Mad Nasir Shamsudin, Zainalabidin Mohamed, "The Impact of Fertilizer Subsidy on Malaysia Paddy/Rice Industry Using a System Dynamics Approach,” Indian J. Med. Sci., vol. 2, no. 3, pp. 213-219, 2012.

[9] W. M. Semasinghe, "Economic and Social Cost of Fertilizer Subsidy on Paddy Farming in Sri Lanka," Int. J. Sci. Res., vol. 3, no. 10, pp. 1261-1267, 2014.

[10] J. A. Hoppin et al., "Pesticide use and chronic bronchitis among farmers in the agricultural health study," Am. J. Ind. Med., vol. 50, no. 12, pp. 969-979, 2007, doi: 10.1002/ajim.20523.

[11] K. P. H. Bogor, A. Kas, and D. A. N. Bank, "Aliran kas dan bank," vol. 0, p. 2017, 2017.

[12] S. Bin Deris and H. Ohta, "A machine-scheduling model for large-scale rice production in malaysia," J. Oper. Res. Soc., vol. 41, no. 8, pp. 713-723, 1990, doi: 10.1057/jors.1990.100.

[13] C. L. Johnson, "Government intervention in the Muda irrigation scheme, Malaysia: 'Actors', expectations and outcomes," Geogr. J., vol. 166, no. 3, pp. 192-214, 2000, doi: 10.1111/j.1475-4959.2000.tb00020.x.

[14] K. Scott, J. Park, and C. Cocklin, "From 'sustainable rural communities' to 'social sustainability': Giving voice to diversity in Mangakahia Valley, New Zealand,” J. Rural Stud., vol. 16, no. 4, pp. 433-446, 2000, doi: 10.1016/S0743-0167(00)00018-8.

[15] H. H. Ghebru and S. T. Holden, "Reverse-share-tenancy and agricultural efficiency: Farm-level evidence from Ethiopia,” J. Afr. Econ., vol. 24, no. 1, pp. 148-171, 2015, doi: 10.1093/jae/eju024.

[16] D. Byerlee, A. De Janvry, and E. Sadoulet, "Agriculture for Development," pp. 1-19, 2010. 